Research Article

\title{
Transforming Triple Cropping System to Four Crops Pattern: An Approach of Enhancing System Productivity through Intensifying Land Use System in Bangladesh
}

\author{
Md. Aminul Islam (D), ${ }^{1}$ Md. Jahedul Islam, ${ }^{2}$ M. Akkas Ali, ${ }^{3}$ \\ A. S. M. Mahbubur Rahman Khan, ${ }^{3}$ Md. Faruque Hossain, ${ }^{3}$ and Md. Moniruzzaman ${ }^{4}$ \\ ${ }^{1}$ On-Farm Research Division, BARI, Masterpara, Gaibandha, Bangladesh \\ ${ }^{2}$ Regional Wheat Research Center, BARI, Shyampur, Rajshahi, Bangladesh \\ ${ }^{3}$ On-Farm Research Division, BARI, Joydebpur, Gazipur, Bangladesh \\ ${ }^{4}$ On-Farm Research Division, BARI, Pabna, Bangladesh
}

Correspondence should be addressed to Md. Aminul Islam; amin.agron@gmail.com

Received 17 December 2017; Accepted 23 April 2018; Published 21 May 2018

Academic Editor: David Clay

Copyright $\odot 2018 \mathrm{Md}$. Aminul Islam et al. This is an open access article distributed under the Creative Commons Attribution License, which permits unrestricted use, distribution, and reproduction in any medium, provided the original work is properly cited.

\begin{abstract}
Changing three crops pattern to four crops can play a potential role for achieving countries food security. With this view to increase crop productivity, production efficiency, land use efficiency, and economic return through intensifying cropping intensity as well as crop diversity by transforming three crops pattern to four crops, the experiment was conducted in High Ganges River Floodplain Soils under the Agro-Ecological Zone (AEZ) 11 at Pali, Durgapur, under the Multilocation Testing Site, Puthia, Rajshahi, for two consecutive years 2014-15 and 2015-16. Four crops pattern mustard-onion/maize-T. Aman rice was tested at on-farm condition over the existing three crops pattern mustard-onion-T. Aman rice. Maize was introduced here as a relay crop with onion to fit it in the four crops pattern. The experiment was laid out in RCB design with six dispersed replications. Two-year crop cycles were completed, and data regarding component crops yield were considered for assessing the performance of the two cropping patterns for making a sense of comparing productivity. Although there was no significant difference in component crops yield between four crops and three crops pattern, as an additional crop, maize tremendously increased the system productivity and economic return of the four crops pattern. Higher rice equivalent yield $28.96 \mathrm{t} \cdot \mathrm{ha} \mathrm{a}^{-1}$ in 2013-14 and 30.95 th ha ${ }^{-1}$ in 2014-15 was recorded from the four crops pattern with a mean rice equivalent yield (REY) $29.95 \mathrm{t} \cdot \mathrm{ha}^{-1}$ over the existing pattern with a mean value $21.76 \mathrm{t} \cdot \mathrm{ha}^{-1}$. However, four crops pattern resulted in higher cultivation cost due to growing maize as an additional crop; nevertheless, it gave the higher gross return, marginal return, marginal benefit cost ratio, and production efficiency. The four crops pattern resulted averagely $37.63 \%$ higher production (REY) compared to the existing three crops pattern. Production as well as land use efficiency were increased by $9.33 \%$ and $19.18 \%$, respectively, from the intensified alternate pattern.
\end{abstract}

\section{Introduction}

Trend of available agricultural land over the time is decreasing with an amount to 1.33 lac ha in 1976 (91.83\% of total land area) that is decreased to 1.27 ha in 2000 with yearly loss of $23,391 \mathrm{ha}$. The area is further dropped to 1.21 lac ha in 2010 with yearly loss of $56,537 \mathrm{ha}$. A sum of $1.13 \mathrm{lac}$ ha land has been lost during the past 34 years from 1976 to
2010. Rate of cropland shifting to nonagricultural land (housing, industry, etc.) is alarming as it is associated with the food security of the country. Total cropland was estimated to be $9,761,450$ ha, $9,439,541$ ha, and $8,751,937$ ha in 1976,2000 , and 2010 with an average decrease of $0.14 \%$ during 1976 to 2000 and $0.73 \%$ during 2000-2010, respectively. Hasan et al. reported the rate of change over the 34 years is $0.30 \%$ which is still declining [1]. 


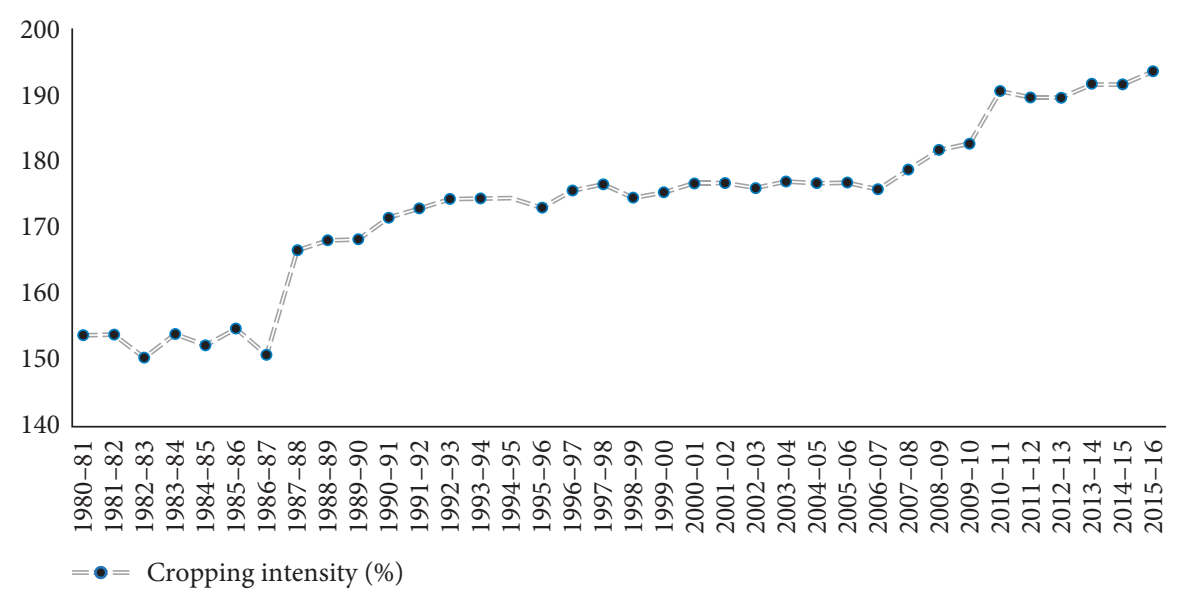

Figure 1: Trend of cropping intensity (\%) in Bangladesh since 1980-81 to 2015-16 (BBS).

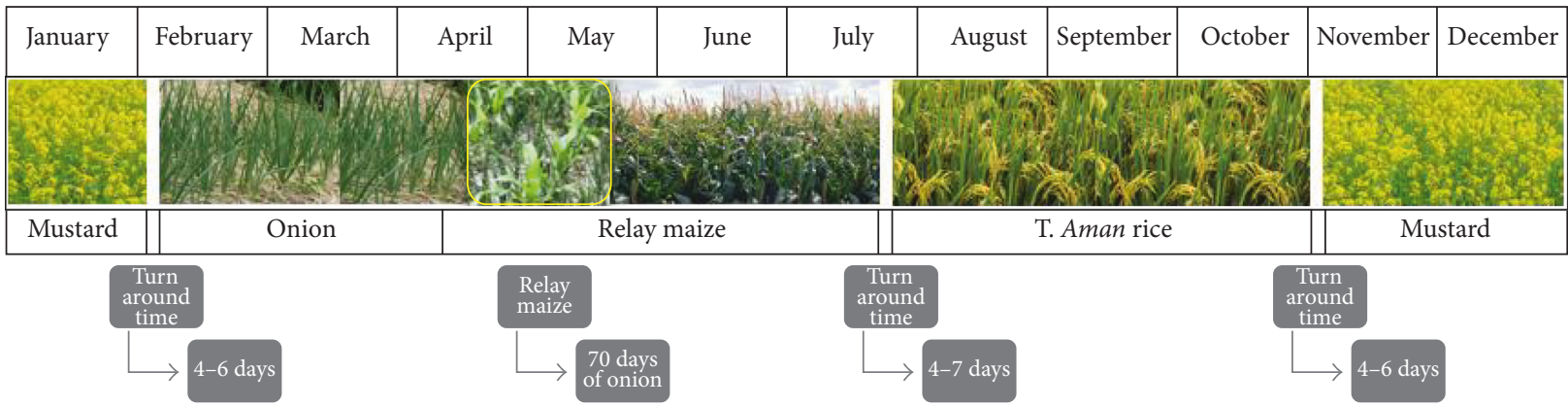

FIGURE 2: Calendar year of four crops pattern.

As per Bangladesh Bureau of Statistics (BBS) [2], around 3795 and 1688 thousand ha of land remain under double and triple cropped area, respectively, which means that $48.41 \%$ and $21.53 \%$ of the country's net cropped area has avenues partly or a major portion to be brought under quadruple cropping system. The area of cropland is decreasing, that is why there is no option of horizontal expansion but intensifying land use system through multiple cropping or by growing more and more crops on the same piece of land in a calendar year. However, the agriculture is heading towards a new paradigm to address the country's food security a concerned issue of Bangladesh. Alauddin and Tisdell [3] investigated that food production has been increased to 3.67 folds over the period of time, from an estimated amount of $1.01 \mathrm{~m}$ ton in 1971 during the independence of Bangladesh to $3.71 \mathrm{~m}$ ton in 2016 as recorded in BBS [2]. Cultivation of modern crop varieties, improvising cultural operations, and crop protection measures as well as increasing crop intensity (Figure 1) collectively contributed to such achievement.

Mustard-onion-T. Aman rice is a popular cropping pattern in Durgapur Upazilla of Rajshahi district under High Ganges River Floodplain. Upazila agricultural office of DAE claims that there are 2000 hectare of land in the upazila in which the pattern mustard-onion-T. Aman rice is being practiced during 2012 cropping year. Mustard is usually grown in Rabi season. Sowing is started in the last week of October to 1st or 2nd week of November, and the crop is harvested in the end of January to mid-February followed by cultivation of onion planted at 2nd week to end of February. After harvest of onion in April, farmers go for T. Aman rice cultivation in the end of July to 2nd or 3rd week of August. Thus, after harvest of onion, the land remains fallow from last week of April to July until T. Aman rice being transplanted. Some commercial maize hybrids grown in Kharif season mature in 95 to 105 days. Therefore, there is a chance of developing four crops pattern as maize can easily be grown as relay crop with onion in between the fallow period as shown in Figure 2. Tanveer et al. [4] reviewed the benefits of relay cropping that enhanced sustainable system productivity through efficient use of available resources like microclimate, nutrients dynamics [5-8]. Inclusion of fourth crop in the sequence will increase system productivity as well as improve farmer's economic condition. Keeping that in the point of view, the study was undertaken to increase diversification and intensification of existing Mustard-onionT. Aman rice cropping pattern in terms of productivity, production efficiency, land use efficiency, and economic return.

\section{Materials and Methods}

2.1. Site Selection. The experiment was conducted at the farmers' field of Pali, Durgapur, under the Multilocation Testing Site (MLT), Shibpur, Puthia, Rajshahi, during 2014-15 to 2015-16 to assess the performance of alternate four crops pattern against existing three crops pattern (mustard-onion-T. 
TABLE 1: Details of cultural practices adopted for different crops in field experiments.

\begin{tabular}{|c|c|c|c|c|c|c|c|c|c|c|c|}
\hline \multirow{2}{*}{ Crop } & \multirow{2}{*}{ Cultivar } & \multirow{2}{*}{$\begin{array}{l}\text { Seed rate } \\
\left(\mathrm{kg} \cdot \mathrm{ha}^{-1}\right)\end{array}$} & \multirow{2}{*}{ Spacing $\left(\mathrm{cm}^{2}\right)$} & \multirow{2}{*}{$\begin{array}{l}\text { Date of } \\
\text { sowing }\end{array}$} & \multirow{2}{*}{$\begin{array}{c}\text { Date of } \\
\text { harvesting }\end{array}$} & \multicolumn{6}{|c|}{ Rate of fertilizer application $\left(\mathrm{kg} \cdot \mathrm{ha}^{-1}\right)$} \\
\hline & & & & & & $\mathrm{N}$ & $\mathrm{P}$ & $\mathrm{K}$ & $\mathrm{S}$ & $\mathrm{Zn}$ & $\mathrm{B}$ \\
\hline Mustard & BARI Sarisha-14 & 07 & $30 \mathrm{~cm}$ solid row & 01-05 Nov & 01-05 Feb & 78 & 15 & 42 & 10 & 2 & 1.5 \\
\hline Onion & BARI Piaz-2 & 08 & $15 \times 10$ & 05-10 Feb & 10-15 May & 93 & 29 & 85 & 19 & 2 & - \\
\hline Maize & NK-40 & 21 & $60 \times 20$ & 10-15 Apr & $15-20 \mathrm{Jul}$ & 250 & 53 & 100 & 40 & - & - \\
\hline T. Aman rice & BRRI dhan33 & 30 & $20 \times 15$ & $20-25 \mathrm{Jul}$ & $25-31$ Oct & 62 & 6 & 19 & 7 & 2 & - \\
\hline
\end{tabular}

Aman rice) in High Ganges River Floodplain soils. Geographically, the experimental field is located at $20^{\circ} 024.49 / \mathrm{N}$ latitude and $88^{\circ} 47.20 / \mathrm{E}$ longitude with the elevation of $20 \mathrm{~m}$ above the sea level. The land was selected based on the discussion with local farmers, DAE personnel, and available secondary information.

2.2. Information Related to AEZ-11. There is an overall pattern of olive-brown silt loams and silty clay loams on the upper parts of floodplain ridges and dark grey, mottled brown, mainly clay soils on ridge sites and in basins. Most ridge soils are calcareous throughout. General soil types predominantly include calcareous dark grey floodplain soils and calcareous brown floodplain soils. Organic matter content in brown ridge soils is low and higher in dark grey soils. Soils are slightly alkaline in reaction. General fertility level is low.

2.3. Nutrient Status. The experimental soil was slightly alkaline (8.4) having low organic matter (1.78\%). The soil contained $0.08 \%$ total $\mathrm{N}$ (very low), $25.85 \mathrm{ppm}$ available $\mathrm{P}$ (optimum), $0.16 \mathrm{me} \%$ exchangeable $\mathrm{K}$ (low), $15.85 \mathrm{ppm}$ available S (medium), $0.50 \mathrm{ppm}$ available $\mathrm{B}$ (high), and $0.20 \mathrm{ppm}$ available $\mathrm{Zn}$ (very low). The rates of the fertilizers for different crops were calculated using soil test values based (STB) on high yield goal as per Fertilizer Recommendation Guide' 2012 [9].

2.4. Experimental Procedure. The experiment was designed with two cropping patterns following randomized complete block design with six dispersed replications. The unit plot size was $8 \mathrm{~m} \times 4 \mathrm{~m}$. The treatments were $\mathrm{C}_{1}$ : mustardonion/maize-T. Aman rice and $\mathrm{C}_{2}$ : mustard-onion-T. Aman rice. The sources of nutrients were urea for N, TSP for $\mathrm{P}, \mathrm{M}_{\mathrm{O}} \mathrm{P}$ for $\mathrm{K}$, gypsum for $\mathrm{S}$, zinc sulphate for $\mathrm{Zn}$, and Boric acid for $\mathrm{B}$. The details of the varieties used and cultural operations adopted in different crop sequences are given in Table 1. For mustard, half of urea and all other inorganic fertilizers were applied according to individual plot and mixed with soil at the time of final land preparation. The rest of urea was top dressed before flowering just one day after first irrigation. In case of onion, half of urea and all other inorganic fertilizers were applied to individual plot and mixed with soil at the time of final land preparation. The rest of urea was top dressed 30 days after planting. Maize was planted 70 days after planting of onion. For maize, half of urea and all other inorganic fertilizers were applied according to individual plot after harvesting of onion at 6leaf stage of maize as side dressing followed by earthing up. The rest urea was top dressed at 10-leaf stage. In case of T. Aman rice, all the fertilizers except urea were applied as basal. Urea was applied as top dress in three equal splits at 15,30 , and 45 days after transplanting. All the crops were harvested at maturity from an area of central $5.0 \mathrm{~m}^{2}$. Data on yield of component crops in sequences were recorded and converted to ton per hectare. Total system productivity was calculated as summation of individual crop yield of each cropping cycle. The productivity of different crop sequences was compared by calculating their economic rice equivalent yield (REY) using formula given by Ahlawat and Sharma [10], where

$$
\operatorname{REY}=\frac{\text { Yield of each crop }\left(\mathrm{t} \cdot \mathrm{ha}^{-1}\right) \times \text { economic value of respective crop }\left(\mathrm{Tk} \cdot \mathrm{t}^{-1}\right)}{\text { Price of rice grain }\left(\mathrm{Tk} \cdot \mathrm{t}^{-1}\right)}
$$

2.4.1. Land Use Efficiency. Land use efficiency (LUE) was estimated by the total duration of crops in the sequence divided by 365 days and expressed in \% as outlined by Jamwal [11]:

$$
\mathrm{LUE}=\frac{\sum \mathrm{Dc}}{365} \times 100
$$

where $\mathrm{Dc}=$ duration of crops in the sequence.

2.4.2. Production Efficiency. Production efficiency (PE) was calculated by taking total economic yield of the sequence on wheat equivalent basis divided duration of crops using per formula by Jamwal [11].

$$
\mathrm{PE}=\frac{\mathrm{REY}}{\sum \mathrm{Dc}}
$$

where $\mathrm{REY}=$ rice equivalent yield in a sequence and $\mathrm{Dc}=$ duration of crops in that sequence.

2.4.3. Marginal Benefit Cost Ratio (MBCR). The economic analysis was done following the method suggested by CIMMYT [12]. The MBCR can be computed as the marginal 
TABle 2: Productivity of component crops (mustard and onion) in different cropping patterns.

\begin{tabular}{|c|c|c|c|c|}
\hline \multirow[b]{2}{*}{ Cropping pattern } & \multicolumn{2}{|c|}{ Cropping year 2013-14 } & \multicolumn{2}{|c|}{ Cropping year 2014-15 } \\
\hline & $\begin{array}{l}\text { Seed yield of } \\
\text { mustard }\left(\mathrm{t} \cdot \mathrm{ha}^{-1}\right)\end{array}$ & $\begin{array}{l}\text { Bulb yield of } \\
\text { onion }\left(\mathrm{t} \cdot \mathrm{ha}^{-1}\right)\end{array}$ & $\begin{array}{c}\text { Seed yield of } \\
\text { mustard }\left(\mathrm{t} \cdot \mathrm{ha}^{-1}\right)\end{array}$ & $\begin{array}{l}\text { Bulb yield of } \\
\text { onion }\left(t \cdot h a^{-1}\right)\end{array}$ \\
\hline Mustard-onion/maize-T. Aman rice & 1.56 & 14.60 & 1.61 & 15.68 \\
\hline Mustard-onion-T. Aman rice & 1.48 & 14.82 & 1.55 & 15.10 \\
\hline Level of significance & NS & NS & NS & NS \\
\hline $\mathrm{SE}( \pm)$ & 0.35 & 0.51 & 0.26 & 0.57 \\
\hline CV (\%) & 4.23 & 5.47 & 5.21 & 4.37 \\
\hline
\end{tabular}

Table 3: Productivity of component crops (maize and T. Aman rice) in different cropping patterns.

\begin{tabular}{|c|c|c|c|c|c|c|c|c|}
\hline \multirow{3}{*}{ Cropping pattern } & \multicolumn{4}{|c|}{ Cropping year 2013-14 } & \multicolumn{4}{|c|}{ Cropping year 2014-15 } \\
\hline & \multicolumn{2}{|c|}{$\begin{array}{l}\text { Yield of maize } \\
\left(\mathrm{t} \cdot \mathrm{ha}^{-1}\right)\end{array}$} & \multicolumn{2}{|c|}{$\begin{array}{l}\text { Yield of T. Aman } \\
\quad \text { rice }\left(\mathrm{t} \cdot \mathrm{ha}^{-1}\right)\end{array}$} & \multicolumn{2}{|c|}{$\begin{array}{l}\text { Yield of maize } \\
\left(\mathrm{t} \cdot \mathrm{ha}^{-1}\right)\end{array}$} & \multicolumn{2}{|c|}{$\begin{array}{l}\text { Yield of T. Aman } \\
\quad \text { rice }\left(\mathrm{t} \cdot \mathrm{ha}^{-1}\right)\end{array}$} \\
\hline & Grain & Stover & Grain & Straw & Grain & Stover & Grain & Straw \\
\hline Mustard-onion/maize-T. Aman rice & 7.65 & 8.43 & 4.54 & 5.88 & 8.39 & 9.13 & 4.77 & 6.06 \\
\hline Mustard-onion-T. Aman rice & - & - & 4.44 & 5.46 & - & - & 4.48 & 5.75 \\
\hline Level of significance & - & - & NS & NS & - & - & NS & NS \\
\hline $\mathrm{SE}( \pm)$ & - & - & 0.36 & 1.23 & - & - & 0.19 & 0.16 \\
\hline $\mathrm{CV}(\%)$ & - & - & 4.59 & 5.74 & - & - & 10.32 & 8.50 \\
\hline
\end{tabular}

value product (MVP) over the marginal value cost (MVC). It can be computed as

$$
\operatorname{MBCR}=\frac{\operatorname{MVP}(\text { over control })}{\operatorname{MVP}(\text { over control })} .
$$

All the data were statistically analyzed following the F-test and the mean comparisons were made by DMRT at $5 \%$ level as per the outline by Gomez and Gomez [13].

\section{Results and Discussion}

3.1. Yield of Mustard. Mustard was the first crop in both the cropping patterns. There was no significant difference of mustard yield in between the cropping patterns. However, numerically higher yield (1.56 t.ha ${ }^{-1}$ in 2013-14 and $1.61 \mathrm{t} \cdot \mathrm{ha}^{-1}$ in 2014-15) was observed in the improved pattern followed the existing one (Table 2).

3.2. Yield of Onion. Onion was the second crop in both the sequences and planted in the late Rabi season (February). There was no significant difference between the cropping patterns on the bulb yield of onion. However, from the 1st year observation, numerically higher bulb yield was recorded in the existing cropping pattern (mustard-onion-T. Aman rice) than four crops pattern. The 2 nd year trend was contrary to the first year result though the difference was statistically nonsignificant (Table 2).

3.3. Yield of Maize. Maize was the included crop in the improved pattern and grown as a relay crop with onion in Kharif-I season (April), whereas, in the existing pattern, this period remained fallow. From the two years' observation, it was clear that maize can effectively be grown as relay with onion to fit it in the four crops pattern by saving time. Inclusion of maize in the fallow period characteristically
TABLE 4: System productivity (REY*) of component crops in different cropping patterns.

\begin{tabular}{lcc}
\hline \multirow{2}{*}{ Cropping pattern } & \multicolumn{2}{c}{ System REY $\left(\mathrm{t} \cdot \mathrm{ha}^{-1}\right)$} \\
& $2013-14$ & $2014-15$ \\
\hline Mustard-onion/maize-T. Aman rice & 28.96 & 30.95 \\
Mustard-onion-T. Aman rice & 21.51 & 22.01 \\
Level of significance & 0.05 & 0.05 \\
SE $( \pm)$ & 2.65 & 2.96 \\
CV $(\%)$ & 6.21 & 8.62 \\
\hline
\end{tabular}

${ }^{*}$ Rice equivalent yield.

increased the system's equivalent yield. Generally, farmers use excess amount of fertilizers for preceding crop onion. Therefore, maize can be grown with a minimum support regarding input cost. However, maize produced 7.65 ton grain and 8.43 ton stover ha ${ }^{-1}$ in 2013-14 and 8.39 ton grain and 9.13 ton stover $\mathrm{ha}^{-1}$ in 2014-15 which contributed to a higher REY of $29.95 \mathrm{t} \cdot \mathrm{ha}^{-1}$ in four crop-based pattern (Tables 3-5). Correia et al. [14] observed 209.57\% higher yield from maize as intercropped/relayed with mucuna.

3.4. Yield of T. Aman Rice. T. Aman rice is the common crop in the Kharif-II (July-October) season in both cropping patterns. Grain yield of T. Aman rice is a complex character depending on a large number of environmental, morphological, and physiological characters. Grain yields also depend upon their yield components. However, there was no significant difference on grain yield of rice in between the cropping patterns but numerically higher $(2.25 \%$ in 2013-14 and $6.47 \%$ in 2014-15) grain yield observed in the imposed pattern might be due to the residual effect of fertilizers applied to the preceding maize crop (Table 3). Jabbar et al. [15] observed the positive impact on residual soil fertility when crops are grown as inter/relay cropping system. 
TABLE 5: Field crop duration, production efficiency, and land use efficiency as influenced by cropping patterns.

\begin{tabular}{lcccc}
\hline Cropping pattern & Mean REY $\left(\mathrm{t} \cdot \mathrm{ha}^{-1}\right)$ & $\begin{array}{c}\text { Field duration of } \\
\text { crop sequence }(\text { day })\end{array}$ & $\begin{array}{c}\text { Production efficiency } \\
\left(\mathrm{kg}^{-1} \cdot \mathrm{ha}^{-1} \cdot \mathrm{day}^{-1}\right)\end{array}$ & $\begin{array}{c}\text { Land use } \\
\text { efficiency }(\%)\end{array}$ \\
\hline Mustard-onion/maize-T. Aman rice & 29.95 & 340 & 88.10 & 93.15 \\
Mustard-onion-T. Aman rice & 21.76 & 270 & 80.58 & 73.97 \\
\hline
\end{tabular}

TABle 6: Profitability of the four crops pattern over the existing pattern.

\begin{tabular}{|c|c|c|c|c|c|}
\hline Cropping pattern & $\begin{array}{l}\text { Gross return } \\
\left(\mathrm{Tk} \cdot \mathrm{ha}^{-1}\right)\end{array}$ & $\begin{array}{c}\text { Cultivation cost (TVC) } \\
\left(\mathrm{Tk} \cdot \mathrm{ha}^{-1}\right)\end{array}$ & $\begin{array}{l}\text { Marginal value } \\
(\mathrm{MVP})\left(\mathrm{Tk} \cdot \mathrm{ha}^{-1}\right)\end{array}$ & $\begin{array}{c}\text { Marginal cost } \\
(\mathrm{MVC})\left(\mathrm{Tk} \cdot \mathrm{ha}^{-1}\right)\end{array}$ & $\mathrm{MBCR}^{*}$ \\
\hline Mustard-onion/maize-T. Aman rice & 539180 & 285542 & 147540 & 46894 & 3.14 \\
\hline Mustard-onion-T. Aman rice & 391640 & 238648 & - & - & - \\
\hline
\end{tabular}

3.5. System Productivity. System productivity was considered as rice equivalent yield (REY). The system REY significantly differed between the cropping patterns. However, data are presented in Table 2. In general, the pattern involving four crops produced significantly greater REY than that having three crops pattern. However, mustard-onion/maize-T. Aman rice showed higher productivity in terms of REY (28.96 th ha ${ }^{-1}$ in 2013-14 and $30.95 \mathrm{t} \cdot \mathrm{ha}^{-1}$ in 2014-15) with a mean REY $29.95 \mathrm{t} \cdot \mathrm{ha}^{-1}$ (Table 5) than mustard-onion-T. Aman rice cropping pattern $\left(21.76 \mathrm{t} \cdot \mathrm{ha}^{-1}\right)$. Total productivity increased by $37.63 \%$ in the maize-included four crops pattern. Mondal et al. [16] also claimed of having 49 to $67 \%$ higher productivity from the intensified land use system. Total field duration of crops by cropping pattern is presented in Table 5. Total field duration was the higher in mustard-onion/maize-T. Aman rice cropping pattern (340 days) due to additional maize crop cultivation and found lower (270 days) in the existing mustard-onion-T. Aman rice cropping pattern because of not cultivating maize in kharif season.

3.6. Production Efficiency (PE). The cropping patterns showed variation on production efficiency (PE) (Table 5). The pattern having four crops generated the higher PE $\left(88.10 \mathrm{~kg}^{-1} \cdot \mathrm{ha}^{-1} \cdot \mathrm{day}^{-1}\right)$. This is due to the higher productivity of this sequence in which the contribution of maize is quite obvious. However, the mustard-onion-T. Aman rice gave the $9.33 \%$ lower PE $\left(80.58 \mathrm{~kg}^{-1} \cdot \mathrm{ha}^{-1} \cdot \mathrm{day}^{-1}\right)$ in the sequences. Higher $\mathrm{PE}$ associated with improved cropping pattern coupled with modern management practices were noted by Nazrul et al. [17], Khan et al. [18, 19], and Krrishna and Reddy [20]. Though not studied here, inter/relay crops could increase system production by suppressing the weed growth [21].

3.7. Land Use Efficiency (LUE). Land use efficiency (LUE) varied according to the cropping patterns (Table 5). In general, patterns intensified by four crops resulted in 19.18\% higher LUE than the triple cropping system. The higher LUE (93.15\%) was recorded in mustard-onion/maize-T. Aman rice whereas the lower LUE (73.97\%) was recorded in mustard-onion-T. Aman rice cropping pattern. The results are in agreement with Kamrozzaman et al. [22].
3.8. Economic Performance. Based on two years' observation, economic performance of the patterns is presented in Table 6 . Cropping pattern attributed a remarkable impact on variable cost, marginal return, and marginal benefit cost ratio (MBCR). The annual gross return, cultivation cost, marginal return, and marginal cost were considered for assessing the suitability of the cropping pattern. In general, inclusion of the fourth crop (maize) markedly enhanced both the return and cultivation cost. Though maize accounted for $19.64 \%$ higher cultivation cost, consequently it contributed to $37.63 \%$ higher return in the four crops pattern. The mustard-onion/maize-T. Aman rice had a maximum gross return (Tk. $539180 \mathrm{ha}^{-1}$ ) along with a higher cultivation cost (Tk. $285542 \mathrm{ha}^{-1}$ ), which also contributed to higher marginal return (Tk. $147540 \mathrm{ha}^{-1}$ ) and MBCR (3.14) than mustard-onion/maize-T. Aman ricebased three crops pattern.

\section{Conclusion}

Relaying maize with onion is a simple but an effective time space saving technology for shifting the thee crops pattern to four crops (mustard-onion/maize-T. Aman rice) one. Considering systems REY, LUE, PE, and economic performances of the two-year crop cycle, it is revealed that four crops pattern is the best option for greater productivity and profitability over the triple cropping system.

\section{Disclosure}

The authors do certify that the statements made by them are true and correct to the best of their knowledge and belief. They understand that any false statements or any unfair means may provide grounds for the withdrawal or cancellation of the manuscript.

\section{Conflicts of Interest}

The authors declare that they have no conflicts of interest regarding the publication of the article.

\section{Acknowledgments}

The authors are thankful to the On-Farm Research Division, Bangladesh Agricultural Research Institute, Gazipur, for providing financial help and logistic support, respectively. 


\section{References}

[1] M. N. Hasan, M. S. Hossain, M. A. Bari, and M. R. Islam, Agricultural Land Availability in Bangladesh, SRDI, Dhaka, Bangladesh, 2013.

[2] BBS (Bangladesh Bureau of Statistics), Yearbook of Agricultural Statistics, Statistics and Informatics Division (SID) Ministry of Planning, Dhaka, Bangladesh, 2016.

[3] M. Alauddin and C. Tisdell, "Trends and projections for Bangladeshi food production: an alternative viewpoint," Food Policy, vol. 12, no. 4, pp. 318-331, 1987.

[4] M. Tanveer, S. A. Anjum, S. Hussain, A. Cerdà, and U. Ashraf, "Relay cropping as a sustainable approach: problems and opportunities for sustainable crop production," Environmental Science and Pollution Research, vol. 24, no. 8, pp. 6973-6988, 2017.

[5] H. Knörzer, H. Grözinger, S. Graeff-Hönninger, K. Hartung, H. P. Piepho, and W. Claupein, "Integrating a simple shading algorithm into CERES-wheat and CERES-maize with particular regard to a changing microclimate within a relay-intercropping system," Field Crops Research, vol. 121, no. 2, pp. 274-285, 2011.

[6] A. C. Gaudin, K. Janovicek, R. C. Martin, and W. Deen, "Approaches to optimizing nitrogen fertilization in a winter wheat-red clover (Trifolium pratense L.) relay cropping system," Field Crops Research, vol. 155, pp. 192-201, 2014.

[7] C. Amossé, M. H. Jeuffroy, B. Mary, and C. David, "Contribution of relay intercropping with legume cover crops on nitrogen dynamics in organic grain systems," Nutrient Cycling in Agroecosystems, vol. 98, no. 1, pp. 1-14, 2014.

[8] J. S. Schepers, D. D. Francis, and J. F. Shanahan, "Relay cropping for improved air and water quality," Journal of Biosciences, vol. 60 , pp. 186-189, 2005.

[9] BARC (Bangladesh Agricultural Research Council), Fertilizer Recommendation Guide, BARC, Farmgate, Dhaka, Bangladesh, 2005.

[10] I. P. S. Ahlawat and R. P. Sharma, Agronomid Terminology, Indian Society of Agronomy, New Delhi, India, 3rd edition, 1993.

[11] J. S. Jamwal, "Productivity and economics of different maize (Zea mays) based crop sequences under dryland conditions," Indian Journal of Agronomy, vol. 46, no. 4, pp. 601-604, 2001.

[12] CIMMYT, From Agronomic Data to Farmer Recommendations: An Economic Training Manual, International Maize and Wheat Improvement Center, El Batan, MEX, Mexico, 1988.

[13] K. A. Gomez and A. A. Gomez, Statistical Procedures for Agricultural Research, An International Rice Research Institute Book, John Wiley and Sons, New York, NY, USA, 2nd edition, 1984.

[14] M. V. Correia, L. C. R. Pereira, L. D. Almeida et al., "Maizemucuna (Mucuna pruriens (L.) DC) relay intercropping in the lowland tropics of Timor-Leste," Field Crops Research, vol. 156, pp. 272-280, 2014.

[15] A. Jabbar, R. Ahmad, I. H. Bhatti, T. Aziz, M. Nadeem, and R. A. Wasi-u-Din, "Residual soil fertility as influenced by diverse rice-based inter/relay cropping systems," International Journal of Agriculture and Biology, vol. 13, pp. 477-483, 2011.

[16] R. I. Mondal, F. Begum, A. Aziz, and S. H. Sharif, "Crop sequences for increasing cropping intensity and productivity," SAARC Journal of Agriculture, vol. 13, no. 1, pp. 135-147, 2015.

[17] M. I. Nazrul, M. R. Shaheb, M. A. H. Khan, and A. S. M. M. R. Khan, "On-Farm evaluation of production potential and economic returns of potato-rice based improved cropping system," Bangladesh Agronomy Journal, vol. 16, no. 2, pp. 41-50, 2013.
[18] M. A. Khan, S. M. A. Hossain, and M. A. H. Khan, "A study on some selected jute-based cropping patterns at Kishoregonj," Bangladesh Journal of Agricultural Research, vol. 31, no. 1, pp. 85-95, 2006.

[19] M. A. H. Khan, M. A. Quayyum, M. I. Nazrul, N. Sultana, and M. R. A. Mollah, "On-farm evaluation of production potential and economics of mustard-rice based improved cropping system," Journal of Social and Economic Development, vol. 2, no. 1, pp. 37-42, 2005.

[20] A. Krishna and A. K. Reddy, "Production potential and economics of different rice (Oryza sativa) based cropping systems in Andhra Pradesh," Indian Journal of Agricultural Sciences, vol. 67, no. 12, pp. 551-553, 1997.

[21] C. Amossé, M. H. Jeuffroy, F. Celette, and C. David, "Relayintercropped forage legumes help to control weeds in organic grain production," European Journal of Agronomy, vol. 49, pp. 158-167, 2013.

[22] M. M. Kamrozzaman, M. A. H. Khan, S. Ahmed, and A. F. M. Ruhul Quddus, "On-farm evaluation of production potential and economics of Wheat Jute-T.aman rice-based cropping system," Journal of the Bangladesh Agricultural University, vol. 13, no. 1, pp. 93-100, 2015. 


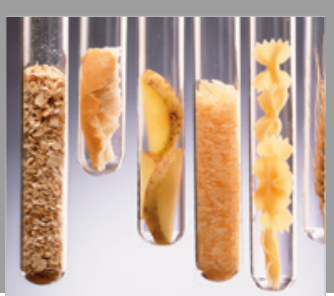

International Journal of Food Science

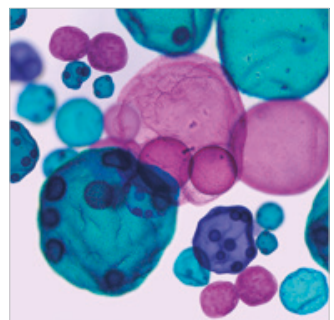

International Journal of Microbiology
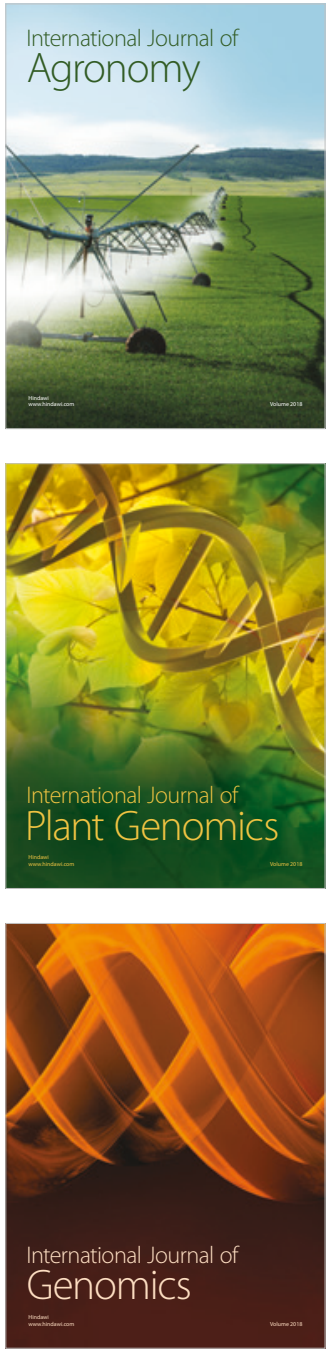

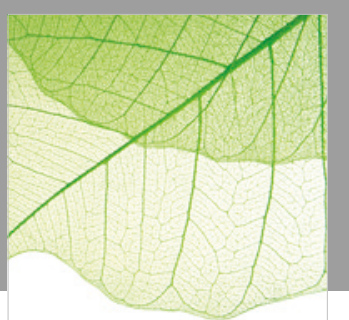

Journal of Botany
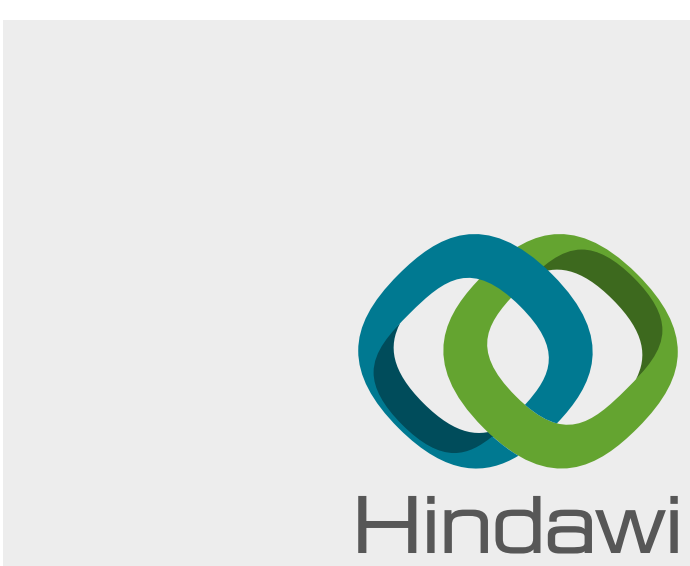

Submit your manuscripts at

www.hindawi.com
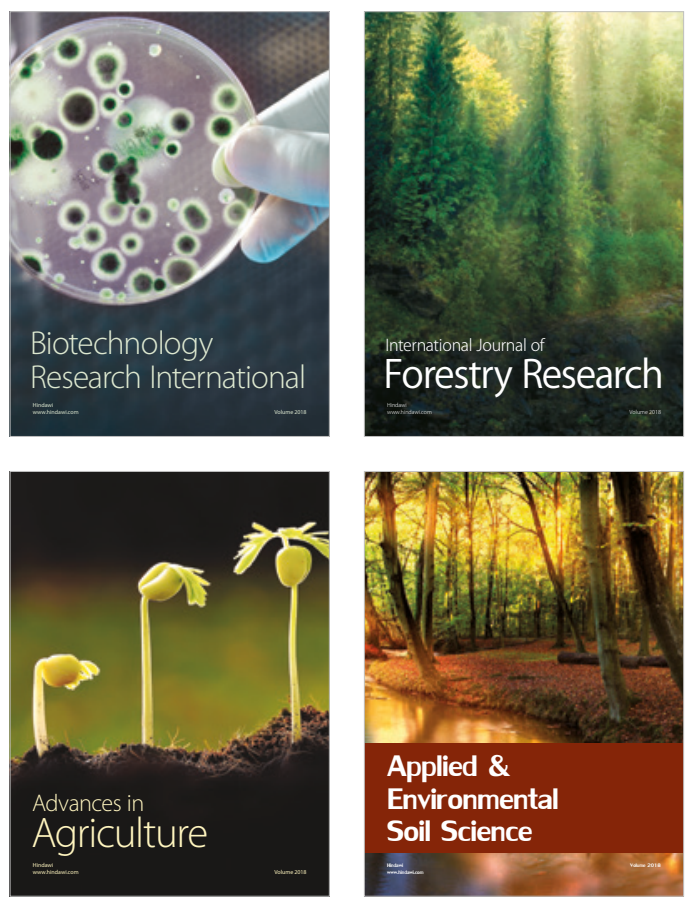

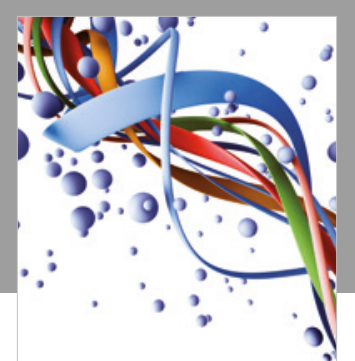

Scientifica

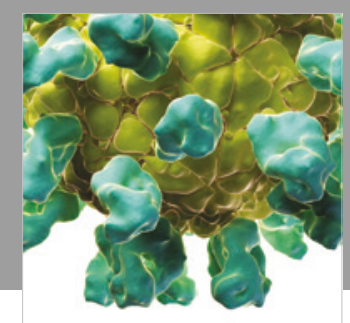

Veterinary Medicine International

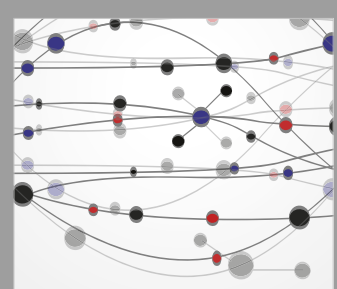

The Scientific World Journal
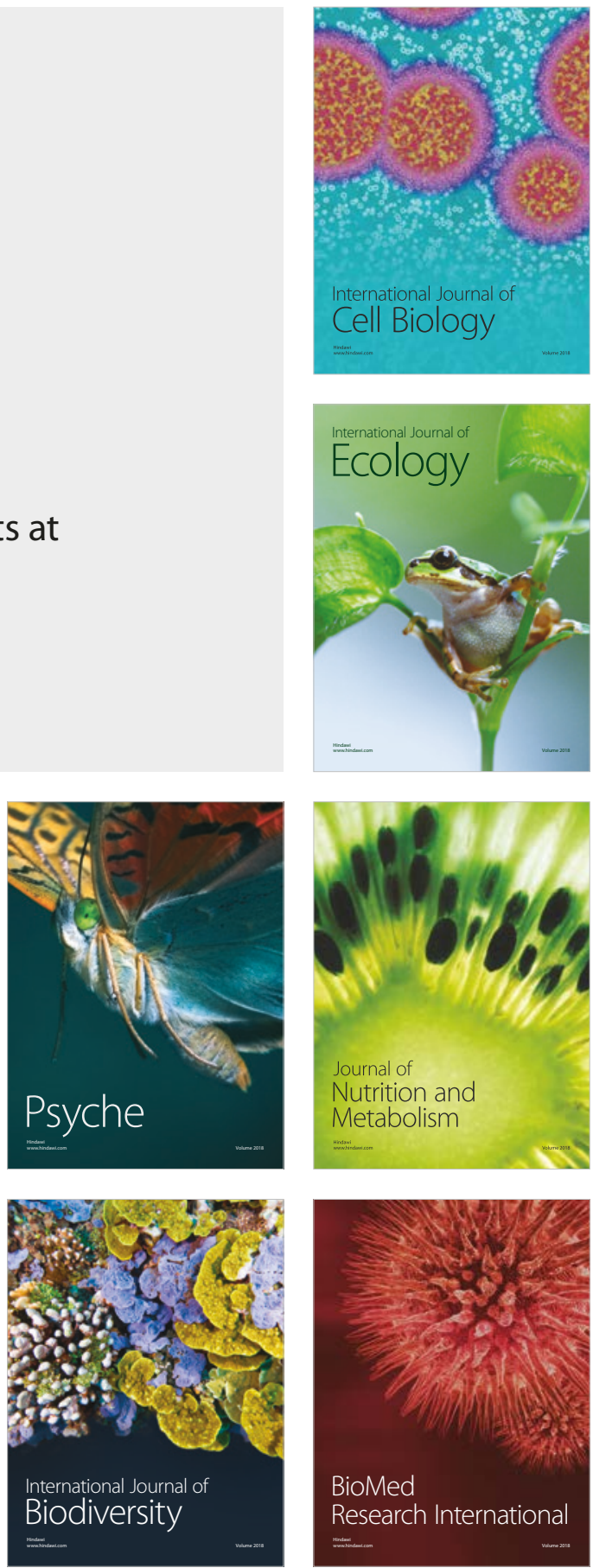